\title{
A poly-e-caprolactone based biofilm carrier for nitrate removal from water
}

\author{
A. L. Rodrigues $\cdot$ A. V. Machado $\cdot$ J. M. Nóbrega $\cdot$ \\ A. Albuquerque $\cdot$ A. G. Brito $\cdot$ R. Nogueira
}

Received: 8 February 2012/Revised: 13 February 2013/Accepted: 3 March 2013/Published online: 26 March 2013

(C) Islamic Azad University (IAU) 2013

\begin{abstract}
Nitrate removal from water has been accomplished by heterotrophic biofilms using organic carbon as a source of reducing power. To overcome the natural limitation in organic carbon in water, a poly-e-caprolactone based biofilm carrier that serves simultaneously as a biofilm carrier and as a source of organic carbon was developed and tested in the present work. The feasibility of the new biofilm carrier for nitrate removal from water was evaluated in a packed bed reactor. The combination of size and structure provided a carrier element having high surface area and void volume, $1,170 \mathrm{~m}^{2} / \mathrm{m}^{3}$ and $67 \%$, respectively. A maximum denitrification rate of $4.4 \mathrm{mg} \mathrm{N}-\mathrm{NO}_{3}{ }^{-} /$(L.h $) \quad(9.2 \mathrm{mg}$ $\left.\mathrm{N}-\mathrm{NO}_{3}{ }^{-} /\left(\mathrm{m}^{2} . \mathrm{h}\right)\right)$ was achieved in the packed bed reactor at $20{ }^{\circ} \mathrm{C}$ and $\mathrm{pH}$ 7.0. Main advantages of the biofilm carrier developed in the present work are its mechanical stability in
\end{abstract}

A. L. Rodrigues - A. G. Brito

IBB-Institute for Biotechnology and Bioengineering,

Centre of Biological Engineering, University of Minho,

Campus de Gualtar, 4700-057 Braga, Portugal

A. L. Rodrigues ( $₫)$

University of Minho-DEB, Campus de Gualtar,

4710-057 Braga, Portugal

e-mail: alexandrina@deb.uminho.pt

A. V. Machado · J. M. Nóbrega

IPC-Institute for Polymers and Composites/I3N, University

of Minho, Campus de Azurém, 4800-058 Guimarães, Portugal

\section{A. Albuquerque}

Department of Civil Engineering and Architecture,

University of Beira Interior, Edifício 2 das Engenharias,

Calça da Fonte do Lameiro, 6201-001 Covilhã, Portugal

R. Nogueira

ISAH-Institute of Sanitary Engineering and Waste Management, University of Hannover, Welfengarten 1,

30167 Hannover, Germany water even after biofilm formation and controlled release of organic carbon by enzymatic reactions. The proposed biotechnology to remove nitrate from groundwater is robust and easy to operate.

Keywords Biodegradable polymer - Biofilm .

Denitrification · Packed bed reactor - Solid carbon source

\section{Introduction}

Nitrate is a persistent pollutant in the environment according to the European Environment Agency and the US Environmental Protection Agency (EEA 2007; USEPA 1993). Water quality of surface- and groundwater has been impaired by high concentrations of nitrate resulting from anthropogenic activities, such as the intensive use of nitrogen fertilizers and the application of manure on land-farming (Wang et al. 2009). Besides the environmental impact, high concentrations of nitrate in the water have negative effects in health and are associated with diseases such as stomach cancer and methemoglobinemia (Wolfe and Patz 2002). These risks led to the adoption of a stringent limit for nitrate concentration in potable water of $50 \mathrm{mgNO}_{3}{ }^{-} / \mathrm{L}$ in different world countries (Drinking Water Directive 98/83/EC; WHO 2008).

Nitrate pollution can be mitigated using both reduction of environmental release and treatment of contaminated water. Several processes have been described in literature to reduce the concentration of nitrate in water. Well-established water treatment processes such as lime softening and filtration are not the most adequate to remove nitrate from water because nitrate is a stable and highly soluble ion with low potential for adsorption or co-precipitation (Heredia et al. 2006). Physical and chemical processes such as reverse osmosis, ion exchange and electrodialysis are 
considered the best available technologies (BAT) to treat nitrate-contaminated water (Haugen et al. 2002). In spite of the high efficiency to remove nitrate, BATs are expensive and present an elevated technological complexity (Della Rocca et al. 2007) compared to biological nitrate removal (Robertson et al. 2000; Su and Puls 2006; Wang et al. 2009). Nitrate can be reduced mainly to dinitrogen gas by the activity of heterotrophic bacteria using organic carbon as the source of electrons (Rivett et al. 2008). This process, known as denitrification, is an important step in the nitrogen cycle in natural systems (Martins et al. 2011), as for example soil, sediments and aquifers, and it has been used extensively in water treatment (Magram 2010) and in the tertiary treatment of wastewater (WEF 2009). Denitrification involves four sequential steps catalyzed by reductase enzymes that reduce nitrate to molecular nitrogen, with nitrite, nitric oxide and nitrous oxide as intermediates. Incomplete denitrification is a potential contributor to nitrous oxide $\left(\mathrm{N}_{2} \mathrm{O}\right)$ production which is one of the main greenhouse gases as reviewed by Kampschreur et al. (2011). A comprehensive review of the denitrification process was not in the scope of this work and can be found elsewhere (Bothe et al. 2007; Wallenstein et al. 2006).

Typically, contaminated water with nitrate is severely limited in organic carbon and the addition of an external soluble carbon source (e.g. acetic acid, sucrose, ethanol and methanol) has been the usual procedure to achieve denitrification (Gomez et al. 2000; Rivett et al. 2008). The main disadvantages associated with the use of liquid carbon sources are the need of a dosing system and the risk of additional contamination of the water with easily degradable organic carbon. Recently, solid carbon sources (e.g. chitin, cotton, sawdust, wheat straw, poly- $\beta$-hydroxybuty-

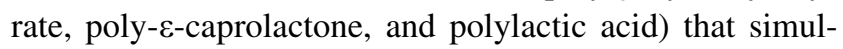
taneously serve as a biofilm carrier and as a source of organic carbon for denitrification were tested mainly at laboratory scale (Hiraishi and Khan 2003; Della Rocca et al. 2005; Della Rocca et al. 2007; Soejima et al. 2010). The use of cotton provided a good nitrate removal performance, but total organic carbon was consistently released to the water (Della Rocca et al. 2005). A performance decrease in the denitrification of reactors packed with raw cotton and wheat straw solid carbon sources was reported in literature, mainly due to compression and subsequent loss of permeability of the bed during testing (Soares et al. 2000; Aslan and Turkman 2005; Della Rocca et al. 2005). Biodegradable polymers such as poly- $\beta$-hydroxybutyrate and poly- $\varepsilon$-caprolactone can be interesting alternative solid carbon sources to cotton and wheat straw because they are relatively resistant to compression and can be extruded with a desirable shape to maximize surface area and porosity of the bed.

Biofilm systems, namely packed bed reactors, have been frequently used in nitrate removal from water (Magram
2010). The present study evaluated the performance of a

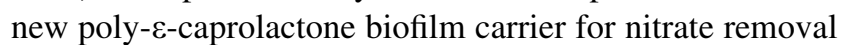
from water in a packed bed reactor. Poly- $\varepsilon$-caprolactone served as a carrier for biofilm growth as well as a carbon source. The geometry of the new carrier combined a high specific surface area for biofilm formation with a high porosity of the bed to avoid clogging problems.

The present study was carried out from 4 July to 30 December 2011 in both Department of Polymers and Department of Biological Engineering of University of Minho.

\section{Materials and methods}

Preparation and characterization of poly- $\varepsilon$-caprolactone based carriers

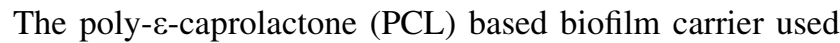
in this study was developed in the Institute for Biotechnology and Bioengineering (IBB) and Institute for Polymers and Composites (IPC) of University of Minho, Portugal. PCL is a biodegradable aliphatic polyester derived from petroleum. The carrier was designed both to maximize the surface area in contact with the water and to minimize the resistance to the water flow in the carriers' bed even after biofilm growth on the surfaces. In this way, it is expected to have active biofilms and prevent clogging of the bed. The carrier's geometry is cylindrical with fourteen projections centrally joined by a septum forming twelve cavities (Fig. 1a); the length and the diameter are $10 \pm 2.00 \mathrm{~mm}$ and $17 \pm 2.00 \mathrm{~mm}$, respectively. The PCL CAPA FB100 used in this work was kindly supplied by Solvay. PCL carriers were prepared by extrusion in a laboratory modular co-rotating twin-screw extruder (Leistritz LSM 30.34). The carrier's density is $750 \mathrm{~kg} / \mathrm{m}^{3}$ and the specific surface area is $1,170 \mathrm{~m}^{2} / \mathrm{m}^{3}\left(0.18 \mathrm{dm}^{2} /\right.$ carrier $)$.

Packed bed reactor

A polyacrylic column (1.04 $\mathrm{m}$ long, $0.042 \mathrm{~m}$ inner diameter) was entirely packed with PCL carriers. The void volume of the packed bed reactor was $67 \%$. The reactor was fed with mineral medium, as previously described in Rodrigues et al. (2012), with increasing concentrations of nitrate $(10,20,30$, 40 and $50 \mathrm{mgN}-\mathrm{NO}_{3}{ }^{-} / \mathrm{L}$ ) during 70 days. The range of nitrate concentrations tested included those frequently found in contaminated aquifers (ITRC 2002). The $\mathrm{pH}$ was adjusted to 7.0 and a microbial mixed culture was used as inoculum. The packed bed reactor was fed in an upflow mode with a liquid velocity of $0.08 \mathrm{~m} / \mathrm{h}$, corresponding to a flow rate of $1.8 \mathrm{~mL} / \mathrm{min}$ regulated by a peristaltic pump (Watson Marlow 101R). To establish anoxic conditions in the packed bed reactor, the medium was flushed with $\mathrm{N}_{2}$. All experiments were conducted at room temperature of $20 \pm 1{ }^{\circ} \mathrm{C}$. 

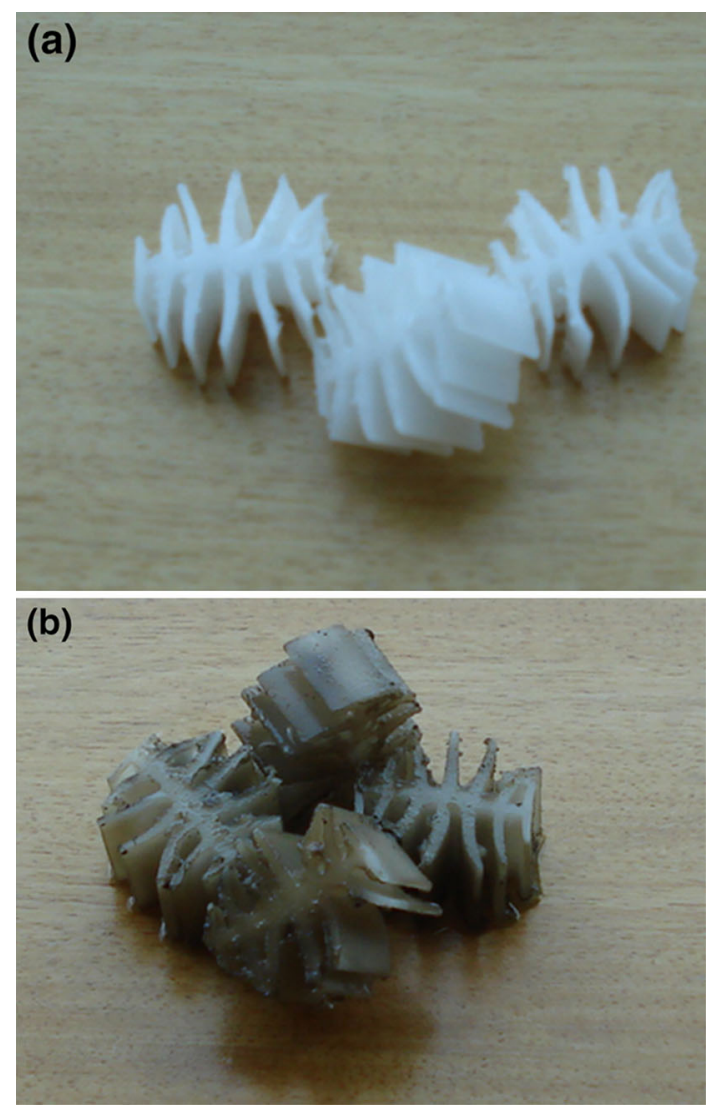

Fig. 1 PCL based biofilm carrier: a clean and $\mathbf{b}$ colonized with biofilm

The residence time distribution curves in the packed bed reactor without (clean PCL carriers) and with biofilm (after 70 days of operation) were determined with the pulse tracer method according to Albuquerque and Santana (2004) using blue dextran as tracer. Adsorption of blue dextran on the PCL carriers was determined to be negligible (data not shown). The dimensional residence time distribution (RTD) curves were calculated with the experimental data. The moment method was used to estimate the first moment on the origin $\mu_{\mathrm{m}}$ (mean residence time) and the second moment on the measuring point $\sigma^{2}$ (variance) of the RTD curves. The degree of dispersion and the extension of dead-volumes were evaluated by the characteristic parameters of the Multiple-Tanks-in-Series model: $N$, the number of tanks in series, and $V_{\mathrm{m}}$, the ratio of dead-volume over total effective volume. Both parameters were estimated by curve-fitting the experimental results with the multi-purpose, nonlinear, least-square meter's method (Albuquerque and Santana 2004). The quadratic error was calculated for a better comparison of the results.

Sampling and analytical methods

Samples were collected in the inlet and in the outlet of the packed bed reactor and filtered with a $0.45 \mu \mathrm{m}$ filter
(514-4,156 membrane disc filters Supor-450, VWR) before analytical determinations. Nitrate and nitrite were measured by spectrophotometric methods according to Standard Methods (APHA et al. 1998). Soluble $\varepsilon$-caprolactone was measured by high performance liquid chromatography (HPLC, Knauer) with a UV-vis detector. Total organic carbon (TOC) was determined by the combustion-infrared method (Rodrigues et al. 2009) using a Shimadzu TOC5000A analyzer (Labonal, Portugal). The biofilm formed on PCL carriers was quantified according to Rodrigues et al. (2010) in the end of the experiments. Briefly, the biofilm was sampled by removing several carriers from the packed bed reactor and placing them aseptically into a falcon tube containing $40 \mathrm{~mL}$ of a sterile buffer solution (Ringer's solution). The tube was vigorously vortexed for $5 \mathrm{~min}$, sonicated for $15 \mathrm{~min}$ in a sonication bath (Model SC-52) and vortexed again for $5 \mathrm{~min}$. Subsequently, the clean carriers were removed, dried (room temperature) and weighted. The biofilm suspension was then homogenized for 20 min using a tissuemizer with SBS-dispensing tool (model AV 5). The biofilm suspension was used to assess the amount of biofilm expressed as volatile suspended solids (VSS) and determined by a gravimetric method according to standard methods (APHA et al. 1998). The decrease in mass of the PCL carrier bed due to hydrolysis was assessed as the weight difference between the clean carrier bed and the carrier bed after biofilm removal in the end of the experiment. The gas composition in $\mathrm{CO}_{2}, \mathrm{~N}_{2} \mathrm{O}$ and $\mathrm{N}_{2}$ was determined by gas chromatography (GC Chrompack CP 9001). Measurements were made in duplicate.

\section{Results and discussion}

\section{Residence time distribution analysis}

The results of the tracer experiments (Fig. 2) showed no significant changes in the bed hydrodynamics after colonization of the carrier by the biofilm. As it can seen in Table 1, the mean residence time and the variance are quite similar. The dimensionless residence time values $\left(\mu_{\mathrm{m}, \theta}\right)$ obtained under both operating conditions (with and without biofilm) are above 1.0 indicating the presence of a significant longitudinal dispersion in the reactor. Regardless of the presence of the biofilm, the results also suggested retention of the tracer in the PCL carrier bed due to the presence of stagnant areas leading to a mean residence time $\left(\mu_{\mathrm{m}}\right) 80 \%$ higher than the theoretical residential time $(\tau)$. The presence of stagnant areas was also observed in other packed bed reactors described in literature (Albuquerque and Bandeiras 2010). The degree of dispersion was high along the bed length for both operating conditions (with and without biofilm) as indicated by a $N$ value (number of tanks in series) of 2, with 


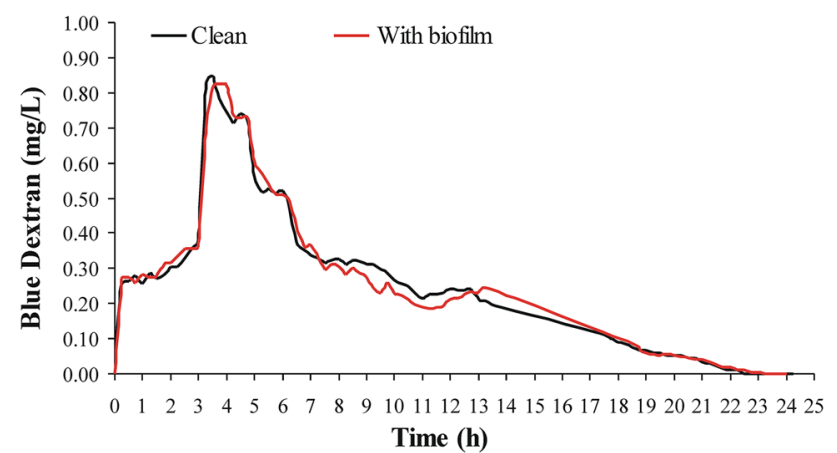

Fig. 2 Concentration of Blue Dextran over time (tracer experiment)

Table 1 Characteristic parameters of the RTD curve

\begin{tabular}{llllll}
\hline Carrier bed & Experiment length $(\mathrm{h})$ & $\tau(\mathrm{h})$ & $\mu_{\mathrm{m}}(\mathrm{h})$ & $\mu_{\mathrm{m}, \theta}$ & $\sigma^{2}$ \\
\hline Clean & 24.3 & 4.2 & 7.6 & 1.79 & 25.9 \\
With biofilm & 24.0 & 4.2 & 7.3 & 1.74 & 26.7 \\
\hline
\end{tabular}

$\tau$ theoretical residential time (effective volume over flow rate), $\mu_{m}$ mean residence time, $\mu_{m, \theta}$ dimensionless residence time, $\sigma^{2}$ variance

similar quadratic errors (0.27). As the $N$ value is low, it can be admitted mixing conditions especially at the entrance of the reactor, which is an area subjected to high hydrodynamic disturbance due to the proximity to the feeding point. Thus, the delay in the exit of the tracer observed in both curves depicted in Fig. 2 might have been associated with stagnant areas. The dead-volume ratio $\left(V_{\mathrm{m}}\right)$ was not significant for both experiments $(<1 \%)$, and, therefore, the presence of the biofilm had no effect in developing dead-volumes during the experimental period (70 days).

\section{Denitrification in a biofilm bed packed with PCL carriers}

The biofilm layer formed on the carrier's surface could be seen with naked eye and presented a brownish colour, as it can be observed in Fig. 1b. The biofilm's VSS increased from $0.89 \mathrm{~g} \mathrm{VSS} / \mathrm{m}^{2}(0.08 \mathrm{~g} \mathrm{VSS} / \mathrm{L})$ to $1.67 \mathrm{~g} \mathrm{VSS} / \mathrm{m}^{2}$ (0.15 VSS g/L) after 70 days of operation of the packed bed reactor. The suspended biomass's VSS at the reactor's outlet was very low $(0.03 \mathrm{~g} / \mathrm{L})$. The decrease in mass of the PCL carrier was $0.03 \mathrm{~g}$ in 70 days of operation of the reactor corresponding to $0.03 \% /$ day. The biofilm carrier maintained a stable structure in water even after biofilm formation and no biomass clogging of the packed bed reactor was observed during the experimental period. These are two advantages of the biofilm carrier presented in the present study compared to others previously described in literature. Previous studies done with other solid carbon sources such as cotton and newspaper showed that these materials were susceptible to compression with the subsequent loss of permeability of the packed bed reactor (Volokita et al. 1996; Soares et al. 2000; Della Rocca et al. 2005).

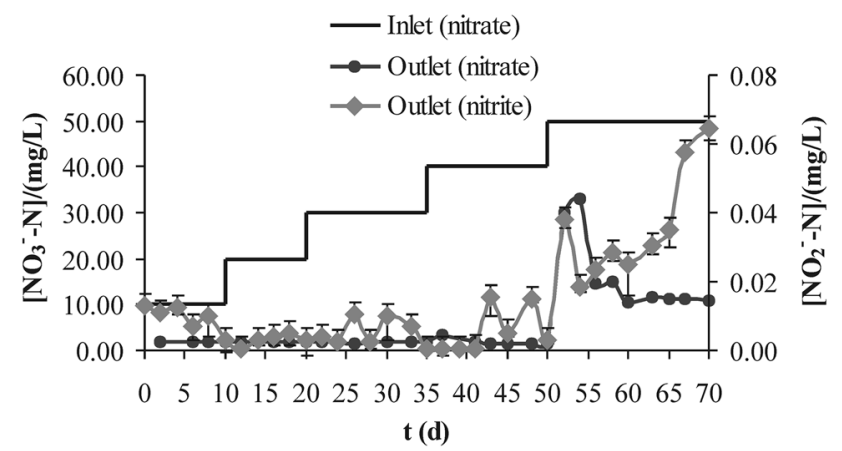

Fig. 3 Nitrate- and nitrite-nitrogen concentrations in the bed packed with the PCL carrier over time

The effect of the nitrate load was studied by changing the inlet nitrate concentration in five subsequent steps from 10 to $50 \mathrm{mg} \mathrm{N}-\mathrm{NO}_{3}{ }^{-} / \mathrm{L}$ (Fig. 3). To secure stable operating conditions after an increase in the inlet nitrate concentration, a minimum period of 2 weeks with similar outlet nitrate concentrations was awaited. Complete nitrate removal was achieved in the packed bed reactor for nitrate concentrations in the range of $10-40 \mathrm{mg} \mathrm{N}-\mathrm{NO}_{3}{ }^{-} / \mathrm{L}$. However, when a concentration of $50 \mathrm{mg} \mathrm{N}-\mathrm{NO}_{3}{ }^{-} / \mathrm{L}$ was tested, the nitrate concentration in the outlet increased to $10 \mathrm{mg} / \mathrm{L} \mathrm{N}-\mathrm{NO}_{3}{ }^{-}$ and remained constant until the end of the experimental time. The maximum nitrate removal rate achieved in the packed bed reactor was $9.2 \mathrm{mg} \mathrm{N}-\mathrm{NO}_{3}{ }^{-} /\left(\mathrm{m}^{2} \mathrm{~h}\right)$ at $20{ }^{\circ} \mathrm{C}$; this value can be alternatively expressed per unit of reactor's volume as $4.4 \mathrm{mg} \mathrm{N}-\mathrm{NO}_{3}{ }^{-} /(\mathrm{L} \mathrm{h})$ or per unit of biomass in the reactor as $131 \mathrm{mg} \mathrm{N}-\mathrm{NO}_{3}{ }^{-} /(\mathrm{g}$ VSS day). The concentration of nitrite was below $0.02 \pm 0.01 \mathrm{mg} \mathrm{N}-\mathrm{NO}_{2}{ }^{-} / \mathrm{L}$ and increased slightly to $0.06 \pm 0.03 \mathrm{mg} \mathrm{N}-\mathrm{NO}_{2}{ }^{-} / \mathrm{L}$ for an inlet nitrate concentration of $50 \mathrm{mg} \mathrm{N}-\mathrm{NO}_{3}{ }^{-} / \mathrm{L}$ (Fig. 3).

The gas composition analyses showed that the values of $\mathrm{N}_{2} \mathrm{O}$ were below $1.9 \%$ for inlet nitrate concentrations between 10 and $40 \mathrm{mg} \mathrm{N}-\mathrm{NO}_{3}{ }^{-} / \mathrm{L}$, and slightly higher $5.8 \%$ for $50 \mathrm{mg} \mathrm{N}-\mathrm{NO}_{3}{ }^{-} / \mathrm{L}$. According to Fernandes et al. (2010), physical, chemical, biological and environmental factors like temperature, $\mathrm{pH}$, organic carbon availability, and composition of the denitrifying community play an important role in $\mathrm{N}_{2} \mathrm{O}$ production. Rassamee et al. (2011) reported that the presence of nitrite, resulting from process disturbance and abrupt changes in a lab-scale sequencing batch reactor fed with real municipal wastewater, is required for $\mathrm{N}_{2} \mathrm{O}$ production by heterotrophic denitrifying bacteria. In the present study, it was not possible to conclude about the factor that induced an increase in the emission of $\mathrm{N}_{2} \mathrm{O}$ because the increase in nitrite concentration after a change in the nitrate load was not significant.

The concentration of soluble $\varepsilon$-caprolactone was below $0.54 \mathrm{mg} / \mathrm{L}(0.15 \mathrm{mg} / \mathrm{L}$ of TOC) for nitrate concentrations lower than $40 \mathrm{mg} \mathrm{N}-\mathrm{NO}_{3}{ }^{-} / \mathrm{L}$, achieving zero for concentrations of 40 and $50 \mathrm{mg} \mathrm{N}-\mathrm{NO}_{3}{ }^{-} / \mathrm{L}$. These results suggested a limitation of nitrate for concentrations lower than 


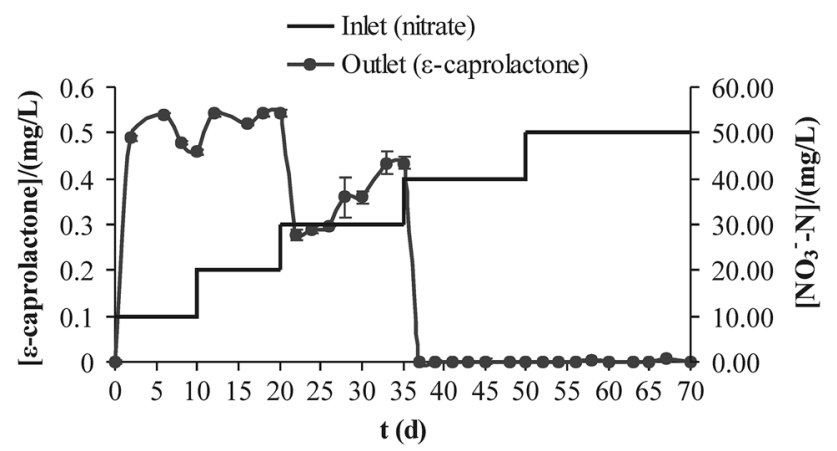

Fig. $4 \varepsilon$-caprolactone and nitrate-nitrogen concentrations in the bed packed with the PCL biofilm based carrier over time

$40 \mathrm{mg} \mathrm{N}-\mathrm{NO}_{3}{ }^{-} / \mathrm{L}$ and a limitation of carbon for higher nitrate concentrations (Fig. 4). It can be concluded that the PCL biofilm carrier used in the present study did not contaminate the water with organic carbon since the maximum value of soluble TOC $(0.15 \mathrm{mg} / \mathrm{L})$ is lower than the limit (4 mg/L) set by USEPA (1998) for drinking water.

Comparison with literature values

Several solid carbon sources were used in water denitrification, as discussed below. In a study of heterotrophic denitrification of nitrate-rich drinking water, Volokita et al. (1996) reported a maximum volumetric nitrate removal rate of $1.54 \mathrm{mg} \mathrm{N}-\mathrm{NO}_{3}{ }^{-} /(\mathrm{L} \mathrm{h})$ at $25^{\circ} \mathrm{C}$ using newspaper shredded to ribbons $(0.4 \mathrm{~cm}$ width) as a carbon source. Using wheat straw, Soares and Abeliovich (1998) obtained a maximum volumetric nitrate removal rate of $2.21 \mathrm{mg}$ $\mathrm{N}-\mathrm{NO}_{3}{ }^{-} /(\mathrm{L} \mathrm{h})$ at $25^{\circ} \mathrm{C}$ which is higher than that of the study done with newspaper. Della Rocca et al. (2005) reported a maximum volumetric nitrate removal rate of $1.0 \mathrm{mg} \mathrm{N}-\mathrm{NO}_{3}{ }^{-} /(\mathrm{L} \mathrm{h})$ at $27^{\circ} \mathrm{C}$ with raw cotton as carbon source that is the lowest value reported in literature, to the author's best knowledge. Information on the available specific surface area of the organic carbon sources tested was not available. The maximum nitrate removal rate obtained in the present study (4.4 mg N-NO${ }_{3}^{-} /(\mathrm{L} \mathrm{h})$ ) is considerably higher than the values above-mentioned. These differences can be attributed to both carbon availability that strongly depends on the composition of the source of organic carbon and the specific surface area available for biofilm formation. A high specific surface area enhances microbial adhesion, and therefore, enzymatic hydrolysis of the polymers. A disadvantage of the above-mentioned studies was the need of a post-treatment of the water coming from the denitrification process (e.g. powdered activated carbon, sand filter) to decrease colour and the concentration of dissolved organic carbon to values lower than $4 \mathrm{mg} / \mathrm{L}$. The present higher cost

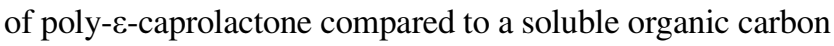
source might hinder a generalised application of this biopolymer in the denitrification process.
Wang and Wang (2009) reported a maximum volumetric nitrate removal rate of $9.41 \mathrm{mg} \mathrm{N}-\mathrm{NO}_{3}{ }^{-} /(\mathrm{L} \mathrm{h})$ at $30{ }^{\circ} \mathrm{C}$ with PCL as the carbon source in groundwater contaminated with nitrate. They studied the effect of the temperature on the volumetric nitrate removal rate and obtained a temperature constant of 0.068 in the range of $10-30{ }^{\circ} \mathrm{C}$. Comparing the volumetric nitrate removal rate obtained by Wang and Wang (2009) at $20{ }^{\circ} \mathrm{C}, 2.4 \mathrm{mg}$ $\mathrm{N}-\mathrm{NO}_{3}{ }^{-} /(\mathrm{L} \mathrm{h})$, with that of the present study, $4.4 \mathrm{mg}$ $\mathrm{N}-\mathrm{NO}_{3}{ }^{-} /(\mathrm{L} \mathrm{h})$, it can be concluded that the literature value is more or less $50 \%$ lower. In an aquaculture system, Boley et al. (2000) reported values of the volumetric nitrate removal rate in the range of $21-166 \mathrm{mg} \mathrm{N}-\mathrm{NO}_{3}{ }^{-} /(\mathrm{L} \mathrm{h})$ or 20-160 mg N- $\mathrm{NO}_{3}{ }^{-} /\left(\mathrm{m}^{2} \mathrm{~h}\right)$, at $25{ }^{\circ} \mathrm{C}$ that are considerably higher than those previously reported both in literature and in the present study. These results cannot be explained by the above-mentioned effect of the temperature in the nitrate volumetric removal rate. One possible explanation is that the PCL used in the different studies have different physical and chemical properties. According to literature, it is well known that the biodegradability decreases with the increase of the molecular weight and the degree of crystallinity of the polymers (Tokiwa et al. 2009). This explanation is speculatory and could not be checked due to missing information in literature. Another explanation is associated with the composition of the water; in the aquaculture system described by Boley et al. (2000), the feed given to the fish contains organic carbon that might have been used for additional nitrate removal.

\section{Conclusion}

The combination of size and structure of the poly- $\varepsilon$-caprolactone based biofilm carrier provided high surface area and void volume $1,170 \mathrm{~m}^{2} / \mathrm{m}^{3}$ and $67 \%$, respectively. A maximum denitrification rate of $9.2 \mathrm{mg} \mathrm{N}-\mathrm{NO}_{3}{ }^{-} /\left(\mathrm{m}^{2} \mathrm{~h}\right)$ was achieved in the packed bed reactor for an inlet nitrate concentration of $40 \mathrm{mg} \mathrm{N}-\mathrm{NO}_{3}{ }^{-} / \mathrm{L}$ at $20{ }^{\circ} \mathrm{C}, \mathrm{pH} 7.0$ and hydraulic retention time of $7.6 \mathrm{~h}$. The reaction was nitrate limited for inlet concentrations lower than $40 \mathrm{mg} \mathrm{N}-\mathrm{NO}_{3}{ }^{-} / \mathrm{L}$ and carbon limited for higher nitrate concentrations. Main advantages of this product are its mechanical stability and controlled release of organic carbon by enzymatic reactions avoiding water contamination and clogging of the bed. A practical aspect related to the operation of a facility using a solid carbon source is the elimination of the carbon dosing system, which facilitates operation. The major disadvantage of biodegradable polymers is its higher cost compared to that of methanol and ethanol.

Acknowledgments The work described in this manuscript was financially supported by FCT by the project "A new generation of biofilm carriers with controlled carbon release properties" (PTDC/ $\mathrm{BIO} / 77936 / 2006)$. This support is gratefully acknowledged. 


\section{References}

Albuquerque A, Bandeiras R (2010) Influence of vegetation in the variation of longitudinal dispersion in Leca-based horizontal subsurface flow beds. In: Proceedings of the 9th International Conference on Hydroinformatics (HIC 2010), 7-11 September 2010, IAHR-IAHSIWA, Tianjin, China, pp 1214-1221. doi:10.1234/12345678

Albuquerque A, Santana F (2004) Hydrodynamic behaviour of a biological packed bed under different hydraulic and organic loading. In: Reis AH, Miguel AF (eds) Applications of Porous Media, Geophysics Centre, Évora, Portugal, 319-327 (ISSN: 9729098360 )

APHA, AWWA, WPCF (1998) Standard Methods for the Examination of Water and Wastewater, 20th edn. American Public Health Association, Washington DC, USA

Aslan A, Turkman A (2005) Combined biological removal of nitrate and pesticides using wheat straw as substrates. Process Biochem 40(2):935-943. doi:10.1016/j.procbio.2004.02.020

Boley A, Müller W-R, Haider G (2000) Biodegradable polymers as solid substrate and biofilm carrier for denitrification in recirculated aquaculture systems. Aquacult Eng 22:75-85. doi:10.1016/ S0144-8609(00)00033-9

Bothe H, Ferguson SJ, Newton WE (2007) Biology of the nitrogen cycle, 1st edn. Elsevier, Amsterdam

Della Rocca C, Belgiorno V, Meriç S (2005) Cotton-supported heterotrophic denitrification of nitrate-rich drinking water with a sand filtration post-treatment. Water SA 31(2):229-236

Della Rocca C, Belgiorno V, Meriç S (2007) Overview of in-situ applicable nitrate removal processes. Desalination 204(1-3): 46-62. doi:10.1016/j.desal.2006.04.023

European Environment Agency (EEA) (2007) Present concentration of nitrate in groundwater bodies in European countries 2003. http:// dataservice.eea.europa.eu/atlas/viewdata/viewpub.asp?id¹/42027

Fernandes SO, Bharathi PAL, Bonin PC, Michotey VD (2010) Denitrification: an important pathway for nitrous oxide production in tropical mangrove sediments (Goa, India). J Environ Qual 39(4):1507-1516. doi:10.2134/jeq2009.0477

Gomez MA, Gonzalez-Lopez J, Hontoria-Garcia E (2000) Influence of carbon source on nitrate removal of contaminated groundwater in a denitrifying submerged filter. J Hazard Mater 80(1-3): 69-80. doi:10.1016/S0304-3894(00)00282-X

Haugen KS, Semmens MJ, Novak PJ (2002) A novel in-situ technology for the treatment of nitrate contaminated groundwater. Water Res 36(14):3497-3506. doi:10.1016/S0043-1354(02)00043-X

Heredia JB, Domínguez JR, Cano Y, Jiménez I (2006) Nitrate removal from groundwater using Amberlite IRN-78: modelling the system. Appl Surf Sci 252(17):6031-6035. doi:10.1016/j.apsusc. 2005.11.030

Hiraishi A, Khan ST (2003) Application of polyhydroxyalkanoates for denitrification in water and wastewater treatment. Appl Microbiol Biotechnol 61(2):103-109. doi:10.1007/s00253-002-1198-y

ITRC (2002) A systematic approach to in situ bioremediation in groundwater: decision trees on in situ bioremediation for nitrates, carbon tetrachloride, and perchlorate. ISB-8. http://www.itrcweb. org/documents/isb-8.pdf

Kampschreur MJ, Temmink H, Kleerebezem R, Jetten MS, van Loosdrecht CM (2011) Nitrous oxide emission during wastewater treatment. Water Res 43(17):4093-4103. doi:10.1016/j.watres.2009.03.001

Magram SF (2010) Drinking water denitrification in a packed bed anoxic reactor: effect of carbon source and reactor depth. J Appl Sci 10(7):558-563. doi:10.3923/jas.2010.558.563

Martins G, Terada A, Ribeiro D, Corral AM, Brito AG, Smets BF, Nogueira R (2011) Structure and activity of lacustrine sediment bacteria involved in nutrient and iron cycles. FEMS Micriobiol Ecol 77(3):666-679. doi:10.1111/j.1574-6941.2011.01145.x

Rassamee V, Sattayatewa C, Pagilla K, Chandran K (2011) Effect of oxic and anoxic conditions on nitrous oxide emissions from nitrification and denitrification processes. Biotechnol Bioeng 108(9):2036-2045. doi:10.1002/bit.23147

Rivett MO, Buss SR, Morgan P, Smith JWN, Bemment CD (2008) Nitrate attenuation in groundwater: a review of biogeochemical controlling processes. Water Res 42(16):4215-4232. doi:10.1016/ j.watres.2008.07.020

Robertson WD, Blowes DW, Ptacek CJ, Cherry JA (2000) Long-term performance on in situ reactive barriers for nitrate remediation. Ground Water 38(5):689-695. doi:10.1111/j.1745-6584.2000.tb02704.x

Rodrigues AL, Brito AG, Janknecht P, Proença MF, Nogueira R (2009) Quantification of humic acids in surface water: effects of divalent cations, $\mathrm{pH}$, and filtration. J Environ Monit 11:377-382. doi:10.1039/B811942B

Rodrigues AL, Pereira MA, Janknecht P, Brito AG, Nogueira R (2010) Biofilms formed on humic substances: response to flow conditions and carbon concentrations. Bioresour Technol 101: 6888-6894. doi:10.1016/j.biortech.2010.03.121

Rodrigues AL, Mosquera-Corral A, Machado AV, Moura I, Matos MI, Brito AG, Nogueira R (2012) Use of biopolymers as solid substrates for denitrification. Water Sci Technol 65(1):105-111. doi:10.2166/wst.2011.835

Soares MIM, Abeliovich A (1998) Wheat straw as substrate for water denitrification. Water Res 32(12):3790-3794. doi:10.1016/S00 43-1354(98)00136-5

Soares MIM, Brenner A, Yevzori A, Messalem R, Leroux Y, Abeliovich A (2000) Denitrification of groundwater: pilot-plant testing of cotton-packed bioreactor and post-microfiltration. Water Sci Tech 42(1-2):353-359

Soejima T, Itoh M, Imamura S (2010) Column experiment on nitrate purification with polylactic acid and iron powder. Water Air Soil Pollut 213(1-4):485-492. doi:10.1007/s11270-010-0402-4

Su C, Puls RW (2006) Removal of added nitrate in cotton burr compost, mulch compost, and peat: mechanisms and potential use for groundwater nitrate remediation. Chemosphere 66(1):9198. doi:10.1016/j.chemosphere.2006.05.015

Tokiwa Y, Calabia BP, Ugwu CU, Aiba S (2009) Biodegradability of plastics. Int J Mol Sci 10(9):3722-3742. doi:10.3390/ijms10093722

USEPA (1993) Nitrogen Control Manual, EPA/625/R-93/010; US Environmental Protection Agency, Office of Wastewater Management, Washington DC

USEPA (1998) National primary drinking water regulations: disinfectants and disinfection byproducts. Final rule Fed. Reg., 63/ 241/69478, Cincinnati

Volokita M, Belkin S, Abeliovich A, Soares MIM (1996) Biological denitrification of drinking water using newspaper. Water Res 30(4):965-971. doi:10.1016/0043-1354(95)00242-1

Wallenstein MD, Myrold DD, Firestone M, Voytek M (2006) Environmental controls on denitrifying communities and denitrification rates: insights from molecular methods. Ecol Appl 16(6):2143-2152. doi:10.1890/1051-0761(2006)016[2143:ECO DCA]2.0.CO;2

Wang XM, Wang JL (2009) Removal of nitrate from groundwater by heterotrophic denitrification using the solid carbon source. Sci Chins Ser B Chem 52(2):236-240. doi:10.1007/s11426-008-0111-7

Wang Q, Feng C, Zhao Y, Hao C (2009) Denitrification of nitrate contaminated groundwater with a fiber-based biofilm reactor. Bioresour Technol 100(7):2223-2227. doi:10.1016/j.biortech.2008.07.057

Water Environment Federation (WEF) (2009) Design of municipal wastewater treatment plants. Manual of Practice 8. ASCE Manual and Report on Engineering Practice 76, 5th edn

Wolfe AH, Patz JA (2002) Reactive nitrogen and human health: acute and long-term implications. AMBIO 31(2):120-125. doi:10.1579/ 0044-7447-31.2.120

World Health Organization (WHO) (2008) Guidelines for drinking water quality, 3rd edn. WHO, Geneva. http://www.who.int/ water_sanitation_health/dwq/fulltext.pdf 